\title{
CRISIS MANAGEMENT TERMINOLOGICAL SYNONYMS
}

\author{
Jiří DVOŘÁK ${ }^{1}$, Michael DAWSON²
}

Review article

$\begin{array}{ll}\text { Abstract: } & \text { Linguistic risks must not affect negatively the quality of risk communication. It is } \\ \text { advisable to know synonyms of the terms belonging to crisis management lexicon together } \\ \text { with the differences in their denotations. Seemingly synonymous terms have to be further } \\ \text { interpreted and classified according to their occurrences and combinations. The analysis } \\ \text { of terminological synonyms may result in the need to reassign a lexical entry, which is } \\ \text { given inappropriate prominence in the current dictionaries and terminological glossaries. } \\ \text { Keywords: } \quad \text { Crisis management, terminology, synonyms, risk, collocation. }\end{array}$

\section{Introduction}

Although English has a large number of synonyms due to a high number of borrowings of French and Latin origin, absolute synonyms are rare. Words are mostly synonymous only in some of their meanings or contexts and are differentiated stylistically, with the words of French and Latin origin typically used for creating a more formal style.

\section{Materials and methods}

The analysis of crisis management terminological synonyms is based on the selected corpus of crisis management, which includes glossaries related to risk management, an online dictionary, a collection of reliable authentic texts (including NATO and EU Directives), and academic papers. The distributions of lemmas and their combinations have been identified and the frequent collocations being used in a corpus have been compared with some dictionary definitions. An empirical approach and frequency-based analysis have been applied in an effort to find evidence of possible misconceptions about language use and to elicit the need for reassigning a lexical entry.

As the research is still in progress, it is beyond the scope of this paper to provide the readers with the final overview of synonyms and the differences among terminological synonyms in different areas of crisis management.

There are different concepts and classifications of synonymy. Synonymy is a horizontal paradigmatic relation of semantic similarity among lexemes of various forms, which are called synonyms (Čermák, 2010).

According to Klégr (Klégr, 2004) three factors are usually considered, i.e. 1) congruence between meanings (i.e. denotative and cognitive contents as well as connotational and pragmatic sememes), which includes the expressive, attitudinal, evaluative, intensification and associative characteristics; 2) congruence between distributions, i.e. the types of texts, in which the expression may occur (it includes the level of formality, genre, specialization, social status, standardization, frequency, etc.); 3) congruence between extensions, or the ranges of meanings, which determine collocability.

Synonyms are intuitively grouped into classes, or paradigms, in which dominant components are those which have the most commonalities with other components and the highest frequency and are therefore, the most familiar (Čermák, 2010).

Filipec mentions the following types of classifications: subject and conceptual, wordforming, contextual, stylistic and word class. These synonymic lines are mutually related through basic conceptual synonyms, the meanings of which are included and specified in the meanings of their constituents (Filipec, 1961).

John Lyons' and Alan Cruse's concept of synonymy includes absolute synonymy, partial synonymy, near synonymy, false synonymy and nonsynonymy (Lyons, 1995; Cruse, 1986). Absolute synonymy, denied by some linguists, has to meet three conditions, i.e. being identical in all their meanings, in all the dimensions of each meaning, and in all contexts (Lyons, 1995). If one of the three above mentioned conditions is not met, then there is partial synonymy. Partial synonyms (sometimes called cognitive or referential synonyms) differ only in non-conceptual or distributional elements of meaning, and their exchange does not change the true value of the proposition. These synonyms,

\footnotetext{
Language Training Centre, University of Defence, Czech Republic, jiri.dvorak@unob.cz

2 Directorate of Environmental Stewardship, Ottawa, Canada, dawson.mt@forces.gc.ca
} 
sometimes called propositional synonyms, mostly do not overlap in the range of their meanings. Near synonyms are partially non-identical in conceptual components, but not necessarily in the distributional ones. False synonyms have meanings that are similar, analogical, but can be hierarchically superordinate, subordinate, possibly coordinate and, if exchanged, shift the meaning of proposition.

On the one hand, terminological synonyms are created in order to reflect reality from a certain perspective in a given area of expertise and experts try to select the most suitable ones from the given linguistic instruments. Such a process is caused by an effort either to create one's own cultural equivalents to the terms of foreign origin, or the necessity to incorporate international terminology into the system of one's mother tongue. There also seems to be a trend in the Czech language to shorten too long terminological collocations (e.g. impact analysis = impaktová analýza vs. analýza dopadu (na životní prostředí, na organizaci, ...); environmental management $=$ environmentální management vs. management životního prostředí) etc. On the other hand, the differentiation within the terminological system reduces the excessive creation of synonyms in the area of terminology (Filipec, 1961). Through this process of differentiation, synonyms lose their identical meanings. They lose the character of synonyms and become words which are coordinate or subordinate. Such a trend is more evident in the case of abstract terms.

\section{Results}

The Oxford Thesaurus of Current English presents damage as a synonym to destruction (Waite, 2006). Cambridge International Dictionary of English describes one of the meanings of the verb "to destroy" as "to cause damage to" (Procter, 2001). Military environmentalists (NATO, 2005) have defined the above mentioned terms in the following way a) damage = any negative impact. Damage to the environment means aggravating the state of the environment by pollution or other types of military activity above the limits determined by special regulations; b) destruction = activities by personnel, vehicles, or equipment that are directly or indirectly responsible for the death or eradication of animals or fish. It is obvious from the above mentioned definitions that despite the fact the terms damage and destruction are often presented as synonyms, they are rather on some intensity scale. Damage (škoda, poškození) reflects a lower negative impact from military activities on the environment than destruction (zničení, zkáza). It is interesting that some military environmentalists proposed the term death to be left out of the definition of destruction, because the death of one or a few animals does not necessarily mean the extinction of animal species (Rimmer, 2003).

Similarly, the terms pollution (mj. znečištění, zkalení, zašpinění,) and contamination (znečištění, zamoření, nakažení, narušení, kontaminace) are considered to be stylistic synonyms. Although at first sight, some substantive collocations can be identified as synonymous, such as environmental pollution/ contamination; soil $\sim / \sim$; groundwater $\sim / \sim$; air $\sim /$; there is a difference between the terms contaminate and pollute (descriptions of substantives are not mentioned): contaminate implies the presence or the influence of something external which by entering into or by coming in contact with a thing destroys the latter's purity; pollute implies that the process which begins with contamination is complete and manifest that what was literally or figuratively pure and clean has lost its clearness or fairness and has become muddy, or filthy, or poisoned. Pollution may therefore be understood as a consequence of contamination, (air pollution vs. the contamination of air by gases). Atmospheric Pollution is e.g. defined as the contamination of the atmosphere by large quantities of gases, solids and radiation produced by the burning of natural and artificial fuels, chemicals and other industrial processes and nuclear explosions (UNDHA, 1992).

The military environmental protection terminology includes the following definitions of the above mentioned terms: a) pollution $=$ the introduction of physical, chemical or biological agents into the environment through military activity which by their nature or their quantity are foreign to the environment; b) contamination = the deposit, absorption or adsorption of radioactive material or of biological or chemical agents on or by structures, areas, personnel or objects (AAP-6, 2008). There are also definitions of contamination caused by individual contaminants, e.g. contamination by POL $=$ the accidental or purposeful spilling or disposal of petroleum, oils, and lubricants on the land from vehicles, equipment, or aircraft operations such as refuelling, maintenance, and storage (Rimmer, 2002).

The synonyms of the term impact are, besides others, influence, effect, impression, results, consequences, repercussions, force, shock, brunt, impetus, and pressure.

The term effect occurs as a synonym of impact quite often, (e.g. secondary environmental effects, adverse environmental $\sim$, long-term contamination $\sim$, negative $\sim$, direct $\sim$, medical $\sim$ ).

The term consequence, also presented as a synonym of impact, has a shifted meaning in the following example: ... activity may have significant impact or consequences. It follows from the above 
example that impact results in consequences. The two-way collocability of these terms is not possible either. While the term consequence may substitute the term impact in almost all Adjective + Substantive collocations (e.g. training impacts/ consequences; operational $\sim \sim$; environmental $\sim /$, etc.) the substitution is not possible in Noun + Noun collocations (e.g. groundwater impact $\neq \sim$ consequence; impact area $\neq$ consequence $\sim$ ).

Some of the synonyms of the term risk are as follows: chance, possibility, danger, peril, jeopardy, hazard, uncertainty, speculation, and venture. Hazard is the most frequently used term for risk, but differences in their meanings are obvious. Risk is the possibility of suffering harm from a hazard. If they were synonyms, we would not find the expressions such as radiation hazards and risks and environmental hazards - assessing risk ... We may define hazard (or cause) as a potential threat to humans and their welfare and risk (or consequence) as the probability of a specific hazard occurrence. The distinction was illustrated by Okrent (Okrent, 1980) who considered two people crossing an ocean, one in a liner and the other in a rowing boat. The main hazard (deep water and large waves) is the same in both cases but the risk (probability of drowning) is very much greater for the person in the rowing boat. Thus while an earthquake hazard can exist in an uninhabited region, an earthquake risk can occur only in an area where people and their possessions exist.
People, and what they value, are the essential point of reference for all risk assessment and for all disasters (Smith, 1996). Similarly, peril is the cause of risk.

It is obvious that the lexemes labelled as synonyms are usually partial synonyms and their meanings overlap only partially and differ in their other variants. In other words, they may be words which are mutually either superordinate or subordinate.

\section{Conclusion}

The lexemes labelled as synonyms are usually partial, not absolute synonyms. Seemingly synonymous words have their own preferred collocates and different preferred senses. They are close synonyms (Cruse, 1986) and differ in their distributions, connotations and, to various degrees, also in denotations. The lessons learned in this area may consequently lead to the changes in the area of terminology and the improved quality of specialized training.

\section{Acknowledgments}

The outcomes presented in this contribution have been acquired as part of the Security Research Project of the Czech Republic on the Methodology of Assessing the Emergency Water Supply on the Basis of Risk Analysis filed under the code VG20102013066.

\section{References}

AAP-6 (2010). NATO Glossary of Terms and Definitions. Brussels, Belgium: NATO Standardization Agency. 2010.

CPNI (2005). Risk Management and Accreditation of Information Systems [online]. Centre for the Protection of National Infrastructure [cit. 2011-10-28]. Available at: http://www.cpni.gov.uk/documents/ publications/2005/2005003-risk_management.pdf.

CRUSE, D. Alan (1986). Lexical Semantics. Cambridge University Press, 1986. 309 p. ISBN 0-521-27643-8.

ČERMÁK, František (2010). Lexikon a sémantika. 1. vyd. Praha : Lidové noviny, 2010. 357 s. ISBN 978-80-7422020-3.

FILIPEC, Josef (1961). Česká synonyma z hlediska stylistiky a lexikologie. Praha, 1961.

Glossary and Acronyms of Emergency Management Terms. Available at http://orise.orau.gov/emi/trainingproducts/files/glossary-emt.pdf

KLÉGR, Aleš (2004). Intralingual and Interlingual Synonymy. [online]. An Online Journal of Modern Philology, Opava, 2004. ISSN 1214-5505 [cit. 2011-09-25]. Available at: http://philologica.net/studia/20040113000002.htm.

Lexicon of UK Civil Protection Terminology [online]. United Kingdom : Cabinet Office, 2011. [cit. 2011-10-23]. Available at: http://www.cabinetoffice.gov.uk/cplexicon

LYONS, John (1995). Linguistic semantics. An introduction. United Kingdom: Cambridge University Press, 1995. 376 p. ISBN 0-521-43877-2.

MILITELlO, Laura, PATTERSON, Emily, BOWMAN, Lynn, WEARS, Robert Lynn (2006). Information Flow during Crisis Management: Challenges to Coordination in the Emergency Operations Center. Springer, London, 2006.

NATO (2005). Environmental Protection Glossary. 2005. Available at CD. 
OKRENT, David (1980). Comments on Societal Risk. Science, 1980. pp. 372-375.

PEARCE, Laurie (2002). Disaster Management and Community Planning, and Public Participation: How to Achieve Sustainable Hazard Mitigation. University of British Columbia, 2002.

PROCTER, Paul (2001). Cambridge International Dictionary of English. Cambridge University Press, 2001. 1792 p. ISBN 0521009855.

RIMMER, Richard (2002). Record of Proceedings. NATO Training Group, Army Subgroup, Environmental Training Working Group. Madrid, 2002.

RIMMER, Richard (2003). Record of Proceedings. NATO Training Group, Army Subgroup, Environmental Training Working Group. Washington, 2003.

SMITH, Keith (1996). Environmental Hazards: Assessing Risk and Reducing Disaster. $2^{\text {nd }}$ ed. New York : Routledge, 1996. 389 p. ISBN 978-0415122047.

UNDHA (1992). International Agreed Glossary of Basic Terms Related to Disaster Management. United Nations Department of Humanitarian Affairs. 1992.

WAITE, Maurice (2006). Oxford Thesaurus of Current English. Oxford University Press, 2006. 504 p. ISBN 0199202877. 